\title{
Testicular features of semi-confined Nellore bulls subjected to immunocastration
}

\section{Características testiculares de touros Nelore semiconfinados submetidos a imunocastração}

\author{
Luciana da Silva Leal-Karolewski ${ }^{1}$ (D); Valmir Fernandes²; Leonardo Acácio Ferreira de Souza ${ }^{3}$; \\ Gustavo de Freitas Baise ${ }^{3}$; Ranulfo Piau Júnior ${ }^{4}$; Rita de Cássia Lima Ribeiro ${ }^{5}$ \\ ${ }^{1}$ Universidade Estadual de Ponta Grossa, Departamento de Zootecnia, Laboratório de Anatomia e Reprodução Animal, \\ Ponta Grossa - PR, Brazil \\ ${ }^{2}$ Universidade Paranaense, Instituto Superior de Ciências Biológicas, Umuarama - PR, Brazil \\ ${ }^{3}$ Autônomo, Umuarama - PR, Brazil \\ ${ }^{4}$ Universidade Paranaense, Curso de Medicina Veterinária, Laboratório de Morfologia, Umuarama - PR, Brazil \\ ${ }^{5}$ Universidade Paranaense, Curso de Medicina Veterinária, Laboratório de Patologia Animal, Umuarama - PR, Brazil
}

\begin{abstract}
This study aimed to evaluate the effect of immunocastration on the scrotal circumference, as well as in the macroscopic and microscopic testicular features in Nellore bulls bred under a semi-confining system for 91 days. Sixty animals were divided into two groups: 30 intact animals (non-vaccinated) and 30 immunocastrated animals. The immunocastrated animals were treated with two anti-GnRH vaccine doses (Bopriva ${ }^{\mathrm{TM}}$ - Zoetis Australia Pty Ltd). The scrotal circumference (SC) was measured on days 0 and 56. Testicular parameters: biometry traits (length, width, and height $-\mathrm{cm}$; volume $-\mathrm{cm}^{3}$ ) and weight (g) was measured on day 91. Three testicles from each group were histologically processed to find the seminiferous tubule diameter and epithelium thickness $(\mu \mathrm{m})$. Data were analyzed in the Minitab 19 statistical software. The macroscopic features (SC, and testes weight, volume, length, width, and height) and the microscopic features (seminiferous tubule diameter and epithelium thickness) were compared between the two groups through Student's $t$-test and Mann-Whitney test. All the values were lower $(p<0.05)$ in animals immunized against $\mathrm{GnRH}$, except for the right testis width and seminiferous tubule diameter. Results indicate that immunization against $\mathrm{GnRH}$ affected testicular development.
\end{abstract}

Keywords: Beef cattle. Biometry. Histology. Immunization. Seminiferous tubules.

\section{RESUMO}

O objetivo do presente estudo foi avaliar o efeito da imunocastração no perímetro escrotal, assim como nas características testiculares macroscópicas e microscópicas de touros Nelore criados em um sistema de semiconfinamento por 91 dias. Sessenta animais foram divididos em dois grupos: 30 animais inteiros (não vacinados) e 30 imunocastrados. Os animais imunocastrados receberam duas doses de uma vacina anti-GnRH (Bopriva - Zoetis Ltda). O perímetro escrotal (PE) foi mensurado nos dias 0 e 56. Parâmetros testiculares: atributos biométricos (comprimento, largura e altura $-\mathrm{cm}$; volume $\mathrm{cm}^{3}$ ) e peso ( $\mathrm{g}$ ) foram medidos no dia 91. Três testículos de cada grupo foram processados para histologia clássica a fim de avaliar o diâmetro e a espessura do epitélio dos túbulos seminíferos $(\mu \mathrm{m})$. Os dados foram analisados pelo software estatístico Minitab ${ }^{\circ}$ 19. As médias das características macroscópicas (PE, peso, volume, comprimento, largura e altura dos testículos) e das microscópicas (diâmetro e espessura do epitélio dos túbulos seminíferos) foram comparadas entre os dois grupos pelos testes t de Student e Mann-Whitney. Todos os valores foram menores $(p<0,05)$ em animais imunizados contra o GnRH, exceto a altura média do testículo direito e o diâmetro do túbulo seminífero. Os resultados indicam que a imunização contra o GnRH afeta o desenvolvimento testicular.

Palavras-chave: Bovinos de corte. Biometria. Histologia. Imunização. Túbulos seminíferos. 


\section{Correspondence to:}

Luciana da Silva Leal-Karolewski

Universidade Estadual de Ponta Grossa, Departamento de Zootecnia, Laboratório de Anatomia e Reprodução Animal Av. General Carlos Cavalcanti, 4748, Uvaranas

CEP: 84030-900, Ponta Grossa - PR, Brasil

e-mail: 1sleal@uepg.br

Received: June 19, 2020

Approved: November 17, 2020

How to cite: Leal-Karolewski LS, Fernandes V, Souza LAF, Baise GF, Piau Júnior R, Ribeiro RCL. Testicular features of semi-confined Nellore bulls subjected to immunocastration. Braz J Vet Res Anim Sci. 2020;57(4):e171210. https://doi. org/10.11606/issn.1678-4456.bjvras.2020.171210

\section{Introduction}

The sexual condition of beef cattle affects the meat production system. Non-castrated animals have some advantages. These include greater body development, which leads to greater meat production and better feed conversion (Machado et al., 2018). However, some difficulties are presented when raising non-castrated males due to their aggressive behavior between themselves and with their handlers (Pérez-Linares et al., 2017). Castration of male animals bred for slaughter purposes is one of the most common livestock management practices (Coetzee et al., 2010) since it reduces their aggressive and sexual behaviors. Castration also leads to an increase in carcass fat deposition which reduces the incidence of blackened meat cuts (Stafford, 2007).

The methods used to castrate bulls can be classified as chemical, physical, and immunological. Chemical sterilization involves an intratesticular injection of a substance that causes caustic or osmotic destruction of the testicular cells, such as lactic acid (Fordyce et al., 1989), ethanol (Canpolat et al., 2006), calcium chloride (Canpolat et al., 2006; Pereira et al., 2018) and sodium chloride (Andrade et al., 2014; Oliveira et al., 2017). These injections may cause adverse testicular edema (Pereira et al., 2018) or scrotal sloughing (Fordyce et al., 1989). Furthermore, the efficiency of chemical castration is influenced by the age of the animals (Andrade et al., 2014; Oliveira et al., 2017). The effectiveness is typically around $50 \%$ between the age of 12 to 15 months (Canpolat et al., 2006).

Physical castration is the most common method used on beef cattle and can be divided into procedures that involve the surgical removal of testes, or methods that interrupt the blood supply, like using a Burdizzo clamp, rubber ring, or latex band in the spermatic cord (Jacinto-Valderrama et al., 2020; Stafford \& Mellor, 2005). In the surgical castration practice, a distal incision is placed in the scrotum to remove the testes, or the scrotum is removed, and the spermatic cords are dissected and cut or pulled until they rupture (Stafford \& Mellor, 2005). Closed and open techniques have also been used. The closed technique leaves the common tunic intact and is recommended for bulls up to $230 \mathrm{~kg}$ of body weight. In the open technique, all the tunics are separated from the testicular vasculature, and tunics and vasculature are ruptured in two phases (Capucille et al., 2002). Despite being the most used method in Brazil (Machado et al., 2018), surgical castration can lead to postoperative complications, additional expenses with labor force and medications, performance loss, stress, and, in some cases, death (Needham et al., 2017).

Considering the issues resulting from castration procedures, a vaccine called anti-GnRH factor ( $\mathrm{GnRH}$ gonadotrophin-releasing hormone) was developed to force the animal's immune system to produce antibodies capable of neutralizing endogenous $\mathrm{GnRH}$. GnRH is a hypothalamic hormone that has an important role in the control of reproductive functions because it regulates the secretion of follicle-stimulating hormone (FSH) and luteinizing hormone (LH) (Monleón et al., 2020; Needham et al., 2017; Oliver et al., 2003; Öztürk \& Bolacali, 2018).

Testosterone is the main steroid hormone produced in the testis. It stimulates the development and secretory activity of male sex organs, sets secondary sexual features, and enhances muscle growth (Hafez et al., 2004). Immunization against $\mathrm{GnRH}$ leads to a decrease in testosterone secretion. Consequently, immunization inhibits testicular growth, reduces the scrotal circumference, and leads to low muscle development (Janett et al., 2012a; Oliver et al., 2003). Gamete production in vaccinated bulls is also affected as these animals show incomplete spermatogenesis, reduced seminiferous tubule diameter, and testicular degeneration (Janett et al., 2012b; Withoeft et al., 2019; Zanella et al., 2009).

The anti-GnRH vaccine is an alternative to surgical castration (Hernandez et al., 2005). However, the reduction in reproductive activity is temporary and fertility returns to normal rates when the circulation of anti-GnRH antibodies declines after the suppressive effect ends (D’Occhio, 1993).

Therefore, this study aimed to compare scrotal circumference, as well as macroscopic (biometry, weight, and volume) and microscopic (the seminiferous tubules diameter and epithelium thickness) testicular features 
between non-castrated and immunocastrated Nellore bulls bred under a semi-confining system for 91 days.

\section{Materials and Methods}

\section{Animal management and experimental design}

The research was conducted at the Experimental Farm of UNIPAR (Paraná University), located in Maria Helena County, Northwestern Paraná State. Sixty (60) non-castrated male Nellore bulls with an average age between 18 to 24 months were used. Animals were housed in plots planted with Brachiaria brizantha and Cynodom spp. and fed on an isoenergetic and isoprotein diet for 91 days.

Bulls were distributed in two groups to preserve homogeneous mean body weight (BW) and body condition score (BCS) at the beginning of the study: non-castrated (NoC, $\mathrm{n}=30$; BW: $365.70 \mathrm{~kg}$; BCS: 6; average age: 21.73 months) and immunocastrated (ImC, $\mathrm{n}=30$; BW: $367.40 \mathrm{~kg}$; BCS: 6; average age: 21.90 months). The BCS was assessed using a scale from 1 to 9 (Spitzer, 1986).

During the immunocastration procedure, ImC animals received two doses of $1.0 \mathrm{~mL}$ of anti-GnRH vaccine (Bopriva ${ }^{\mathrm{TM}}$ - Zoetis Australia Pty Ltd) by subcutaneous injection, in the anterior half of the neck, using an appropriate injector, on experimental days 0 and 30, following the manufacturer's recommendations.

\section{Data collection}

The scrotal circumference (SC $-\mathrm{cm}$ ) was measured using a tape in the median region at the widest scrotal sac point after pushing the testes in the ventrocaudal direction (Colégio Brasileiro de Reprodução Animal, 2013).

The animals were slaughtered at the end of the experimental period using previous stunning through pneumatically powered stunners followed by bleeding. The testes recovered at the time the animals were slaughtered (day 91) were dissected with the aid of autoclaved scissors and anatomical tweezers. Testicular weight $(\mathrm{g})$, volume $\left(\mathrm{cm}^{3}\right)$ and biometry $(\mathrm{cm})$ were characterized after dissection. The testes were individually weighed on a digital scale (Gehaka - model: BG440). The testicular volume was set by placing each testis in a vessel containing water and by measuring the water volume leaked from the vessel. This was done with the aid of a measuring cylinder. Testicular measurements (length, width, and height) were performed with the aid of a digital caliper (Mitutoxo). The testicular length was measured through the dorsoventral distance, testicular width measured through the lateral-medial distance, and testicular height corresponded to the testis thickness, in the cranial-caudal direction.

Six (6) randomly selected tests (three from each group) were processed for the histological assessment of the testicular tissue according to the classic histology routine technique used in the Veterinary Pathology Sector at UNIPAR Veterinary Hospital. The testes were sectioned in half, fixed in $10 \%$ formalin for $24 \mathrm{~h}$, kept in $70 \%$ alcohol, dehydrated, diaphanized, and embedded in paraffin. The paraffin-embedded material was sectioned in microtome (5 $\mu \mathrm{m}$ thickness) and subjected to Hematoxylin/ Eosin staining per Kiernan (2001).

Testicular images were collected using appropriate equipment (MOTIC ${ }^{\circ}$ ), and the diameter and epithelium thickness of the seminiferous tubules was measured using the Motic Images Plus 2.0 software. Thirty (30) measurements were taken for each variable in each processed testis.

\section{Statistical analysis}

Minitab 19 statistical software was used. For statistical analysis, the Kolmonogorov-Smirnov test was used to verify the normality of the data. Differences between treatments were tested for significance using Student's $t$-test. The Mann-Whitney test was used for non-parametric variables (left testis width and seminiferous tubule epithelium thickness). For all analyses, a $p$-value of $<0.05$ was considered significant.

\section{Results}

Table 1 shows that SC assessed on experimental days 0 and 56 were affected by immunocastration on day $56(p=0.000)$.

Table 2 shows the mean RTW (right testis weight), LTW (left testis weight), RTV (right testis volume), LTV (left testis volume), RTL (right testis length), LTL (left testis length), RTW $_{\mathrm{i}}$ (right testis width), $\mathrm{LTW}_{\mathrm{i}}$ (left testis width), RTH (right testis height) and LTH (left testis height) values found in the $\mathrm{NoC}$ and ImC groups. All measurements were smaller $(p<0.05)$ for the ImC animals in all comparisons, except for RTWi. This difference in biometry was easily recognized by looking at the testes recovered at the time of slaughter (Figure 1).

Table 3 shows the microscopic measurements (diameter and epithelium thickness of the seminiferous tubules) performed in the testicular parenchyma of animals belonging to the two experimental groups. The epithelium of the seminiferous tubules (Figure 2) in the NoC bulls was thicker than that of the bulls belonging to the $\operatorname{ImC}$ group $(p=0.000)$. 
Table 1 - Mean values for the scrotal circumference $(\mathrm{cm})$ of intact and immunocastrated Nellore bulls (Maria Helena, 2020)

\begin{tabular}{ccccc}
\hline \multirow{2}{*}{$\begin{array}{c}\text { Experimental } \\
\text { days }\end{array}$} & $\begin{array}{c}\text { Scrotal circumference (cm) } \\
\text { Treatments }\end{array}$ & \multirow{2}{*}{ SEM } & p-value \\
\cline { 2 - 3 } & \multicolumn{2}{c}{ Intact Immunocastrated } & & \\
\hline Day 0 & 30.88 & 30.72 & 0.25 & 0.746 \\
Day 56 & 34.09 & 30.27 & 0.39 & 0.000 \\
\hline
\end{tabular}

$\mathrm{SEM}=$ standard error of the means. Student's $t$-test $(p<0.05)$.

Table 2 - Mean values for weight, volume, length, width, and height of bovine testes, in the intact and immunocastrated groups (Maria Helena, 2020)

\begin{tabular}{|c|c|c|c|c|}
\hline \multirow{2}{*}{ Item } & \multicolumn{2}{|c|}{ Treatments } & \multirow{2}{*}{ SEM } & \multirow{2}{*}{$p$-value } \\
\hline & Intact & Immunocastrated & & \\
\hline RTW (g) & 179.40 & 127.35 & 6.91 & 0.000 \\
\hline LTW (g) & 172.85 & 125.99 & 6.08 & 0.000 \\
\hline $\mathrm{RTV}\left(\mathrm{cm}^{3}\right)$ & 173.68 & 119.44 & 6.63 & 0.000 \\
\hline $\operatorname{LTV}\left(\mathrm{cm}^{3}\right)$ & 168.37 & 119.08 & 6.12 & 0.000 \\
\hline $\mathrm{RTL}(\mathrm{cm})$ & 10.47 & 9.49 & 0.18 & 0.004 \\
\hline LTL (cm) & 10.36 & 9.47 & 0.17 & 0.008 \\
\hline $\mathrm{RTW}_{\mathrm{i}}(\mathrm{cm})$ & 5.46 & 5.09 & 0.10 & 0.086 \\
\hline $\operatorname{LTW}_{\mathrm{i}}(\mathrm{cm})$ & 5.40 & 4.83 & 0.10 & 0.002 \\
\hline $\mathrm{RTH}(\mathrm{cm})$ & 5.09 & 4.72 & 0.08 & 0.021 \\
\hline LTH $(\mathrm{cm})$ & 5.03 & 4.70 & 0.07 & 0.018 \\
\hline
\end{tabular}

$\mathrm{SEM}=$ standard error of the means; RTW = right testis weight; LTW = left testis weight; RTV = right testis volume; LTV = left testis volume; $\mathrm{RTL}=$ right testis length; LTL = left testis length; $\mathrm{RTW}_{\mathrm{i}}=$ right testis width; $\mathrm{LTW}_{\mathrm{i}}=$ left testis width; RTH = right testis height; $\mathrm{LTH}^{\mathrm{i}}=$ left testis height. Student's $t$-test and Mann-Whitney test $(p<0.05)$.

Table 3 - Mean values for the seminiferous tubule/diameter $(\mu \mathrm{m})$ and epithelium thickness $(\mu \mathrm{m})$ in testes of bovine animals belonging to the intact and immunocastrated groups (Maria Helena, 2020)

\begin{tabular}{ccccc}
\hline \multirow{2}{*}{ Item } & \multicolumn{2}{c}{ Treatments } & SEM & p-value \\
\cline { 2 - 5 } & Intact & Immunocastrated & & \\
\hline $\begin{array}{c}\text { Seminiferous tubule } \\
\text { diameter }(\mu \mathrm{m})\end{array}$ & 192.64 & 186.74 & 2.47 & 0.233 \\
$\begin{array}{c}\text { Seminiferous } \\
\text { tubule epithelium } \\
\text { thickness }(\mu \mathrm{m})\end{array}$ & 61.49 & 42.84 & 1.17 & 0.000 \\
\hline
\end{tabular}

SEM $=$ standard error of the means. Student's $t$-test and Mann-Whitney test $(p<0.05)$.

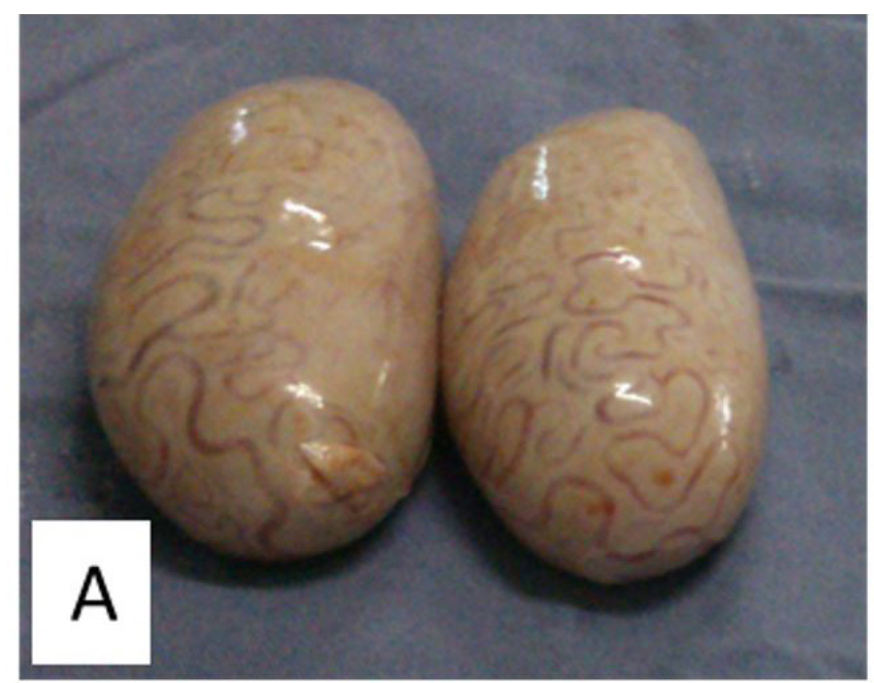

\section{Discussion}

Unanian et al. (2000) studied the testicular biometric features of 402 Nellore bulls (age: 18 months old; mean body weight - BW: $308.06 \mathrm{~kg}$ ) and found mean SC of $23.68 \mathrm{~cm}$. This value was well below that found in $\mathrm{NoC}$ and $\mathrm{ImC}$ groups analyzed in the present study. The difference may be due to the animals' age and to the higher mean initial weight of the $\mathrm{NoC}(365.70 \mathrm{~kg})$ and $\operatorname{ImC}(367.40 \mathrm{~kg})$ animals on day 0. According to Yokoo et al. (2007) and Marques et al. (2013), there is a positive correlation between SC and live weight.

Valentim et al. (2002) assessed the SC of 190 Nellore bulls and found values such as $27.40 \mathrm{~cm}$ in 20 -month-old animals $(B W=336 \mathrm{~kg}$ ) and $29.20 \mathrm{~cm}$ in 24-month-old bulls (BW $=368 \mathrm{~kg}$ ). The SC in 24-month-old animals resembled the results found in the $\mathrm{NoC}$ and $\mathrm{ImC}$ animals on day 0 in the present study since their body weights were similar. However, the NoC animals showed higher SC $(34.10 \mathrm{~cm})$ on day 56 due to live weight increase $(439.43 \mathrm{~kg})$. Despite the body weight $(445.77 \mathrm{~kg}$ ) found in the immunocastrated group on day $56, \mathrm{SC}$ decreased to $30.30 \mathrm{~cm}$.

Godfrey et al. (1989), Zanella et al. (2009), and Janett et al. (2012a) compared the SC between intact and immunocastrated bulls and found decreased SC in the immunocastrated group. According to Zanella et al. (2009), the SC of immunocastrated animals $(22 \pm 5.98 \mathrm{~cm})$ was 8 times smaller than that of the control group $(35.6 \pm 2.4 \mathrm{~cm})$ at the time the animals were slaughtered; the experimental period lasted 741 days. This result was also reported by Janett et al. (2009) for equine species, as well as by Gökdal et al. (2010) for ovine species.

Bertol et al. (2015) compared the right and left testes of 10 castrated Tabapuã bulls (age: 36 to 84 months old; mean weight $560 \mathrm{~kg})$ and found RTW $(275.4 \pm 93.8 \mathrm{~g})$, LTW $(265.7 \pm 94.8 \mathrm{~g}), \operatorname{RTL}(13.2 \pm 1.7 \mathrm{~cm}), \operatorname{LTL}(12.9 \pm 1.5 \mathrm{~cm})$, $\operatorname{RTW}_{\mathrm{i}}(6.5 \pm 1.1 \mathrm{~cm})$ and $\operatorname{LTW}_{\mathrm{i}}(6.4 \pm 1 \mathrm{~cm})$ values higher

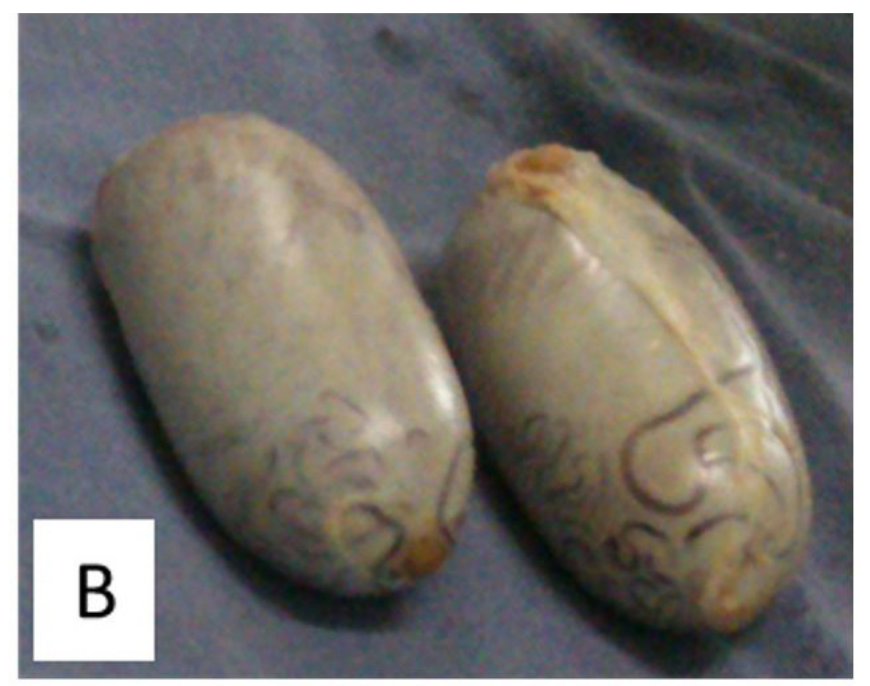

Figure 1 - Testes of the intact bulls (A) and immunocastrated bulls (B). 

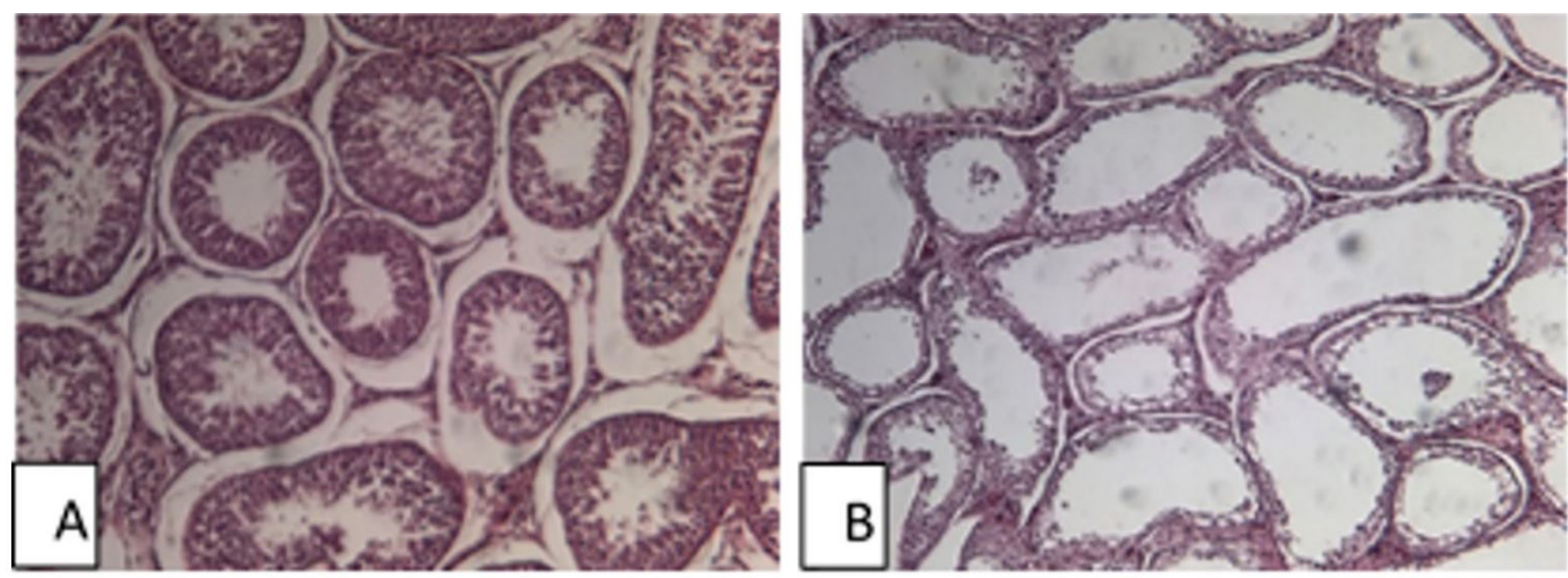

Figure 2 - Seminiferous tubules of the intact bulls (A) and immunocastrated bulls (B) H-E. 10x.

than those found in the $\mathrm{NoC}$ and $\operatorname{ImC}$ animals assessed in the present study. Such a result may be explained by the difference in the age and body weight of the assessed animals. On the other hand, the RTH $(4.84 \pm 0.4 \mathrm{~cm})$ and LTH $(4.7 \pm 0.5 \mathrm{~cm})$ values were lower in Tabapuã than in NoC Nellore bulls $($ RTH $=5.09 \mathrm{~cm}$ and LTH $=5.03 \mathrm{~cm}$ ), because the testes of Nellore animals are more elongated than the those of other Indian breeds (Monteiro et al., 2011; Segui et al., 2011; Silveira et al., 2010).

Studies conducted comparative analyses between the right and left bovine testes and did not find significant measurement differences between them. This confirmed testes symmetry throughout the animal's growth (Guimarães et al., 2003; Machado et al., 2012; Pastore et al., 2008; Unanian et al., 2000).

Boligon et al. (2010) reported testicular volume $327.62 \pm 148.09 \mathrm{~cm}^{3}$ in 18-month-old Nellore bulls; this volume was higher than that found in $\mathrm{NoC}\left(171.03 \mathrm{~cm}^{3}\right)$ and ImC animals $\left(114.94 \mathrm{~cm}^{3}\right)$. The testicular volume in the present study was measured through the extravasation of liquid in a measuring cylinder. On the other hand, Boligon et al. (2010) used the following mathematical calculation to find this result: $\mathrm{V}=2 \mathrm{x}\left(\mathrm{r}^{2} \mathrm{x} \pi \mathrm{xh}\right)$, wherein $\mathrm{r}=$ radius calculated from the width (width / 2), $\pi=3.14$ and $\mathrm{h}=$ length or height. Bovine breeds show different testicular shapes: long, fairly long, oval long, spherical long, and spherical (Siqueira et al., 2012). Testicular length is different from testicular height; therefore, these measures could not be considered equal in the formula. This aspect may explain the difference in the results.

As shown previously, the immunization against GnRH negatively affected the scrotal circumference, testicular size, weight, and volume in the present study. Several additional authors highlighted this occurrence in bovine
(Assumpção et al., 2017; D’Occhio et al., 2001; Godfrey et al., 1989; Janett et al., 2012a; Withoeft et al., 2019), swine (Jaros et al., 2005), and ovine species (Gökdal et al., 2010).

Bopriva $^{\mathrm{TM}}$ is an anti-GnRH vaccine developed specifically for use in cattle. It contains a modified form of $\mathrm{GnRH}$ conjugated to a protein that generates a body response, stimulating the animal's immune system to produce specific antibodies capable of neutralizing the circulating endogenous hormone (Campal-Espinosa et al., 2020; Pérez-Linares et al., 2017). GnRH is released from the hypothalamus and it is responsible for the pituitary production and release of LH and FSH, which act in the production of androgens and spermatogenesis, respectively (Yitbarek \& Regasa, 2014). In this way, immunocastrated animals show a decrease in testosterone levels and, consequently, a decrease in testicular development (Janett et al., 2012a).

Immunization against $\mathrm{GnRH}$ affected the testicular histology and decreased the seminiferous tubule epithelium thickness. The seminiferous tubule epithelium is mainly composed of Sertoli cells, whose base is located at the tubule periphery and extends towards the center of it (Frandson et al., 2011; Garner \& Hafez, 2004). It is known that the pituitary FSH promotes the growth of Sertoli cells (Hafez et al., 2004) and, since their secretion is inhibited by the immunization against $\mathrm{GnRH}$, this explains the decreased seminiferous tubule epithelium thickness resulting from inadequate growth and dysfunction of these cells (Zanella et al., 2009).

According to Janett et al. (2012b), vaccinated bulls presented incomplete spermatogenesis, impaired spermatid production, and reduced seminiferous tubule diameter. In addition to these aspects mentioned, Withoeft et al. (2019) also detected grade 1, 2, and 3 testicular degeneration in young Angus x Limousin bulls. Gökdal et al. (2010) also reported decreased seminiferous tubule diameter in ovine 
species. Monleón et al. (2020) suggested that the effect of vaccination is more effective in reducing the seminiferous tubule diameter when calves are vaccinated at a low live weight, before puberty. The present study did not find reduced seminiferous tubule diameter, which may be a result of the short experimental period (91 days).

\section{Conclusion}

The immunization against GnRH (application of Bopriva $^{\mathrm{TM}}$ ) has effectively receded the testicular development, thus affecting the macro and microscopic features of the male gonad.

\section{References}

Andrade O No, Gasperin BG, Rovani MT, Ilha GF, Nóbrega JE Jr, Mondadori RG, Gonçalves PBD, Antoniazzi AQ. Intratesticular hypertonic sodium chloride solution treatment as a method of chemical castration in cattle. Theriogenology. 2014;82(7):1007-11. http://dx.doi. org/10.1016/j.theriogenology.2014.07.020. PMid:25149022.

Assumpção TI, Barros JPMM, Macedo GG. Efeito da imunocastração sobre o perímetro escrotal e a produção espermática em touros da raça Nelore. Bol Ind Anim. 2017;74(3):294-9. http://dx.doi.org/10.17523/bia.v74n3p294.

Bertol MAF, Weiss RR, Kozicki LE, Abreu ACMR. Biometrics and sperm parameters between right and left testes and epididymis of zebu bulls. Arch Vet Sci. 2015;20(2):156-63.

Boligon AA, Silva JAV, Sesana RC, Sesana JC, Junqueira JB, Albuquerque LG. Estimation of genetic parameters for body weights, scrotal circumference, and testicular volume measured at different ages in Nellore cattle. J Anim Sci. 2010;88(4):1215-9. http://dx.doi.org/10.2527/jas.20081719. PMid:19966155.

Campal-Espinosa AC, Junco-Barranco JA, Fuentes-Aguilar F, Calzada-Aguilera L, Bover CA. Contraception and immunocastration vaccines. Use in veterinary medicine. Rev Colomb Cienc Anim Recia. 2020;12(2):e763. http:// dx.doi.org/10.24188/recia.v12.n2.2020.760.

Canpolat I, Gur S, Gunay C, Bulut S, Eroksuz H. An evaluation of the outcome of bull castration by intra-testicular injection of ethanol and calcium chloride. Rev Med Vet. 2006;157(8-9):420-5.

\section{Conflict of Interest}

The authors declare that there is no conflict of interest.

\section{Ethics Statement}

The research was conducted under the approval of the Ethical Committee for Animal Research of UNIPAR (protocol 24440/2013).

\section{Acknowledgements}

The authors are grateful to Paraná University (UNIPAR) for their financial support.

Capucille DJ, Poore MH, Rogers GM. Castration in cattle: techniques and animal welfare issues North Carolina state university. Compendium. 2002;24(9):S66-73.

Coetzee JF, Nutsch AL, Barbur LA, Bradburn RM. A survey of castration methods and associated livestock management practices performed by bovine veterinarians in the United States. BMC Vet Res. 2010;6(1):12. http:// dx.doi.org/10.1186/1746-6148-6-12. PMid:20199669.

Colégio Brasileiro de Reprodução Animal. Manual para exame andrológico e avaliação de sêmen animal. 3. ed. Belo Horizonte: CBRA; 2013.

D’Occhio MJ, Aspden WJ, Trigg TE. Sustained testicular atrophy in bulls actively immunized against GnRH: potential to control carcase characteristics. Anim Reprod Sci. 2001;66(1-2):47-58. http://dx.doi.org/10.1016/S03784320(01)00091-4. PMid:11343841.

D’Occhio MJ. Immunological suppression of reproductive functions in male and female mammals. Anim Reprod Sci. 1993;33(1-4):345-72. http://dx.doi.org/10.1016/03784320(93)90123-9.

Fordyce G, Hodge PB, Beaman NJ, Laing AR, Campero C, Shepherd RK. An evaluation of calf castration by intratesticular injection of a lactic acid solution. Aust Vet J. 1989;66(9):272-6. http://dx.doi.org/10.1111/j.1751-0813.1989. tb13950.x. PMid:2684125.

Frandson RD, Wilke WL, Fails AD. Anatomia e fisiologia dos animais de fazenda. 7. ed. Rio de Janeiro: Guanabara Koogan; 2011. Capítulo 25, Fisiologia da reprodução masculina; p. 331-42. 
Garner DL, Hafez ESSE. Espermatozoides e plasma seminal. In: Hafez ESSE, Hafez B, editors. Reprodução animal. 7. ed. Barueri: Manole; 2004. p. 97-110.

Godfrey RW, Randel RD, Rouquette FM Jr. Effect of zeranol on sexual development of crossbred bulls. J Anim Sci. 1989;67(7):1751-6. http://dx.doi.org/10.2527/ jas1989.6771751x. PMid:2768123.

Gökdal O, Atay O, Ulker H, Kayaardi S, Kanter M, Deavila MD, Reeves JJ. The effects of immunological castration against $\mathrm{GnRH}$ with recombinant OL protein (OvalbuminLHRH-7) on carcass and meat quality characteristics, histological appearance of testes and pituitary gland in Kivırcik male lambs. Meat Sci. 2010;86(3):692-8. http:// dx.doi.org/10.1016/j.meatsci.2010.06.006. PMid:20650573.

Guimarães JD, Vasconcelos COP, Guimarães SEF, Costa EP, Miranda T No. Biometria testicular em bovinos da raça Nelore, dos 20 aos 22 meses de idade. Rev Bras Reprod Anim. 2003;27(2):173-4.

Hafez ESSE, Jainudeen MR, Rosnina Y. Hormônios, fatores de crescimento e reprodução. In: Hafez ESSE, Hafez B, editors. Reprodução animal. 7. ed. Barueri: Manole; 2004. p. 33-53.

Hernandez JA, Zanella EL, Bogden R, Avila DM, Gaskins CT, Reeves JJ. Reproductive characteristics of grass-fed, luteinizing hormone-releasing hormone immunocastrated Bos indicus bulls. J Anim Sci. 2005;83(12):2901-7. http:// dx.doi.org/10.2527/2005.83122901x. PMid:16282630.

Jacinto-Valderrama RA, Sampaio GSL, Lima MLP, Cyrillo JNSG, Pflanzer SB. Immunocastration on performance and meat quality of Bos indicus (Nellore) cattle under different nutritional systems. Sci Agric. 2020;78(2):e20190136. http:// dx.doi.org/10.1590/1678-992x-2019-0136.

Janett F, Stump R, Burger D, Thun R. Suppression of testicular function and sexual behavior by vaccination against $\mathrm{GnRH}$ (Equity ${ }^{\mathrm{mm}}$ ) in the adult stallion. Anim Reprod Sci. 2009;115(1-4):88-102. http://dx.doi.org/10.1016/j. anireprosci.2008.11.011. PMid:19128902.

Janett F, Gerig T, Tschuor AC, Amatayakul-Chantler S, Walker J, Howard R, Bollwein H, Thun R. Vaccination against gonadotropin-releasing fator (GnRF) with Bopriva significantly decreases testicular development, serum testosterone levels and physical activity in pubertal bulls. Theriogenology. 2012a;78(1):182-8. http://dx.doi.org/10.1016/j. theriogenology.2012.01.035. PMid:22541323.
Janett F, Gerig T, Tschuor AC, Amatayakul-Chantler S, Walker J, Howard R, Piechotta M, Bollwein H, Hartnack S, Thun R. Effect of vaccination against GnRF (Bopriva ${ }^{\oplus}$ ) in the prepubertal bull calf. Anim Reprod Sci. 2012b;131(12):72-80. http://dx.doi.org/10.1016/j.anireprosci.2012.02.012. PMid:22440457.

Jaros P, Bürgi E, Stärk KDC, Claus R, Hennessy D, Thun R. Effect of active immunization against $\mathrm{GnRH}$ on androstenone concentration, growth performance and carcass quality in intact male pigs. Livest Prod Sci. 2005;92(1):31-8. http:// dx.doi.org/10.1016/j.livprodsci.2004.07.011.

Kiernan JA. Histological \& histochemical methods. 3rd ed. New York: Oxford University Press; 2001.

Machado DS, Alves DC Fo, Argenta FM, Brondani IL, Martini APM. Serum levels of testosterone and performance of surgical or immunocastrated beef steers. Comum Sci. 2018;9(3):303-11. http://dx.doi.org/10.14295/cs.v9i3.2498.

Machado PP, Sousa AL, Reis LF, Chaves RM. Mathematical models and correlations of morphometric measurements of testicular and crossbred cattle fed slaughtered in São Luís, MA. Rev Bras Reprod Anim. 2012;36(1):51-61.

Marques EG, Magnabosco CU, Lopes FB, Silva MC. Estimate the genetic parameters of growth characteristics, carcass and scrotal perimeter in Nellore evaluated in weight gain performance tests in feedlot. Biosci J. 2013;29(1):159-67.

Monleón E, Noya A, Garza MC, Ripoll G, Sanz A. Effects of an anti-gonadotrophin releasing hormone vaccine on the morphology, structure and function of bull testes. Theriogenology. 2020;141:211-8. http://dx.doi.org/10.1016/j. theriogenology.2019.07.019. PMid:31387698.

Monteiro FM, Oliveira LZ, Oliveira CS, Tetzner TAD, Mercadante MEZ, Branco RH, Garcia JM. Evaluation of sexual maturity of young bulls from different breeds selected for post-weaning weight. B Indústr Anim. 2011;68(1):37-43.

Needham T, Lambrechts H, Hoffman C. Castration of male livestock and the potential of immunocastration to improve animal welfare and production traits: invited review. S Afr J Anim Sci. 2017;47(6):6-10. http://dx.doi. org/10.4314/sajas.v47i6.1.

Oliveira FC, Ferreira CER, Haas CS, Oliveira LG, Mondadori RG, Schneider A, Rovani MT, Gonçalves PBD, Vieira AD, Gasperin BG, Lucia T Jr. Chemical castration in cattle with intratesticular injection of sodium chloride: effects on stress 
and inflammatory markers. Theriogenology. 2017;90:1149. http://dx.doi.org/10.1016/j.theriogenology.2016.12.001. PMid:28166957.

Oliver WT, Mccauley I, Harrell RJ, Suster D, Kerton DJ, Dunshea FR. A gonadotropin-releasing factor vaccine (Improvac) and porcine somatotropin have synergistic and additive effects on growth performance in group-housed boars and gilts. J Anim Sci. 2003;81(8):1959-66. http:// dx.doi.org/10.2527/2003.8181959x. PMid:12926778.

Öztürk Y, Bolacali M. Effect of immunocastration vaccine administration at different doses on performance of feedlot Holstein bulls. Kocatepe Vet J. 2018;11(3):301-8.

Pastore AA, Toniollo GH, Lôbo RB, Fernandes MB, Vozzi PA, Vila RA, Galerani MAV, Elias FP, Cardilli DJ. Biometric, testicular, seminal characteristics and genetic parameters of pertaining bulls to the program of genetic improvement of the Nellore race. Ars Vet. 2008;24(2):134-41.

Pereira LF, Dias FGG, Miguel MP, Honsho CS, Tavares DC, Hellú JAA, Souza FF. Testicular histological evaluation and serum testosterone concentrations of bulls after chemical castration with calcium chloride. Pesq Vet Bras. 2018;38(8):1554-63. http://dx.doi.org/10.1590/1678-5150pvb-4945.

Pérez-Linares C, Bolado-Sarabia L, Figueroa-Saavedra F, Barreras-Serrano A, Sánchez-López E, Tamayo-Sosa AR, Godina AA, Ríos-Rincón F, García LA, Gallegos E. Effect of immunocastration with Bopriva on carcass characteristics and meat quality of feedlot Holstein bulls. Meat Sci. 2017;123:45-9. http://dx.doi.org/10.1016/j. meatsci.2016.08.006. PMid:27614179.

Segui MS, Turra TA, Faleiros E, Weiss RR, Kosicki LE, Santos IW. Correlation between testicular biometry, age and the reproductive characteristics of Nellore bulls. Arch Vet Sci. 2011;16(1):1-6.

Silveira TS, Siqueira JB, Guimarães SEF, Paula TAR, Miranda T No, Guimarães JD. Sexual maturity and reproductive parameters of Nellore bulls, raised under pasture conditions. Rev Bras Zootec. 2010;39(3):36-9.

Siqueira JB, Oba E, Pinho RO, Guimarães SEF, Miranda T No, Guimarães JD. Testicular shape and andrological aspects of young Nellore bulls under extensive farming. Rev Bras Zootec. 2012;41(3):612-7. http://dx.doi.org/10.1590/ S1516-35982012000300020.
Spitzer JC. Influences of nutrition on reproduction in beef cattle. In: Morrow DA. Current therapy in theriogenology. 2nd ed. Philadelphia: W. B. Saunders; 1986. p. 231-4.

Stafford KJ, Mellor D. The welfare significance of the castration of cattle: a review. N Z Vet J. 2005;53(5):271-8. http://dx.doi. org/10.1080/00480169.2005.36560. PMid:16220117.

Stafford K. Alleviating the pain caused by the castration of cattle. Vet J. 2007;173(2):245-7. http://dx.doi.org/10.1016/j. tvjl.2005.11.002. PMid:16377221.

Unanian MM, Silva AEDF, McManus C, Cardoso EP. Testicular biometrics characteristics to evaluate the Nellore zebu breed bulls. Rev Bras Zootec. 2000;29(1):136-44. http:// dx.doi.org/10.1590/S1516-35982000000100019.

Valentim R, Arruda RP, Barnabé RC, Alencar MM. Testicular biometry of Nellore (Bos taurus indicus) and crossbred bulls (Bos taurus indicus $\mathrm{x}$ Bos taurus taurus) at 20 and 24 months of age. Braz J Vet Res Anim Sci. 2002;39(3):11320. http://dx.doi.org/10.1590/S1413-95962002000300001.

Withoeft JA, Chiocca M, Santiani F, Costa LS, Mateus KA, Santos MR, Casagrande RA, Cucco DC. Anatomopathological evaluation of young bulls (Bos taurus) testicles submitted to immunocastration. Acta Sci Vet. 2019;47(1):1695. http:// dx.doi.org/10.22456/1679-9216.97771.

Yitbarek MB, Regasa F. Reproductive immunization of domestic wild animals: review. Int J Res Agric Sci. 2014;1(2):103-14.

Yokoo MJ, Albuquerque LG, Lôbo RB, Sainz RD, Carneiro JM Jr, Bezerra LAF, Araújo FRC. Estimation of genetic parameters for hip height, weight and scrotal circumference in Nelore cattle. Rev Bras Zootec. 2007;36(6):1761-8. http:// dx.doi.org/10.1590/S1516-35982007000800008.

Zanella R, Zanella EL, Reeves JJ, Hernandez J, Motta AC, Avila D. Testicular characteristics of bulls immunosterilized with anti-luteinizing hormone-releasing hormone vaccine. Pesqui Agropecu Bras. 2009;44(10):1359-63. http://dx.doi. org/10.1590/S0100-204X2009001000021.

Financial Support: Paraná University (UNIPAR). 